\title{
Antioxidant Effect of Grape Seed Proanthocyanidin Extract against Potassium Dichromate Induced Oxidative DNA Damage in Small Intestine of Adult Male Albino Rats
}

\author{
Mona Mohamed Abo El-Noor'1, Naglaa Ibrahim Sarhan, and Khaled Ahmed \\ Moustafa $^{2}$
}

${ }^{1}$ Department of Forensic Medicine and Clinical Toxicology
${ }^{2}$ Department of Histology

Faculty of Medicine, Tanta University, Tanta, Egypt.

\begin{abstract}
Background: Chromium usage is increasing worldwide. Oral exposure to hexavalent chromium Cr (VI) in animals and humans causes various health hazards. $\mathrm{Cr}$ (VI) compounds are classified as class I human carcinogens. Antioxidants were reported to inhibit chemical carcinogenesis. Grape seed proanthocyanidin extract (GSPE), naturally occurring compounds, have antioxidant, anti-inflammatory, anti-allergic and anti-tumor activities.

Objectives: Accordingly, this work was conducted to investigate the antioxidant effect of GSPE against oxidative DNA damage induced by potassium dichromate on small intestine of adult male albino rats through biochemical and microscopic study.

Study design: Forty adult male albino rats were included in this study and divided into four equal groups. Group I served as control group. Group II received $100 \mathrm{mg} / \mathrm{kg} /$ day GSPE. Group III was treated with $15 \mathrm{mg} / \mathrm{kg}$ /day potassium dichromate. Group IV received both $\mathrm{K}$ dichromate and GSPE in their previous doses. All animals were treated orally by syringe feeding method for two months. Body weight, plasma and tissue malondialdehyde (MDA) and total thiol (T-SH) of all studied groups were measured. In addition, light microscopic examination of small intestine using hematoxylin and eosin stains and immunostaining for detection of p53 positive cells as well as scanning electron microscopic examination were carried out.

Results: The current study showed that adult male albino rats treated orally with potassium dichromate showed decrease in body weight, significant increase in plasma and intestinal tissue MDA and significant decrease in plasma and intestinal tissue thiol level. All these changes were associated with severe histological alterations in the wall of the small intestine especially the duodenum with significant increase of $\mathrm{p} 53$ positive cells. GSPE were found to counteract the toxic effect of potassium dichromate by attenuating oxidative stress and DNA damage.

Conclusion: It is concluded that GSPE is promising as an agent that can potentially reduce $\mathrm{K}$ dichromate induced toxic effects in small intestine through its antioxidant effect.
\end{abstract}

Keywords p53, grape seed proanthocyanidin extract (GSPE), malondialdehyde (MDA), total thiol (T-SH), potassium dichromate, small intestine

Introduction

$\longrightarrow$ hromium $(\mathrm{Cr})$ is the $21^{\text {st }}$ most abundant element in the Earth's crust. It is a naturally occurring element found in rocks, volcanic dust and gases, soil as well as plants and animals (Krebs, 2006).

While several valence states of $\mathrm{Cr}$ are possible, only the trivalent $\mathrm{Cr}$ (III) and hexavalent $\mathrm{Cr}$ (VI) forms have significant environmental stability. Most of the naturally occurring chromium is in the $\mathrm{Cr}$
(III) form as chromite ore (Stoecker, 2004) and in salts used as micronutrients and dietary supplements (Pechova and Pavlata, 2007), while Cr (VI) salts such as potassium dichromate $\left(\mathrm{K}_{2} \mathrm{Cr}_{2} \mathrm{O}_{7}\right)$ or chromic acid tend to occur as a result of anthropogenic uses. These include pigments, metal finishing (including chromium plating), leather tanning, stainless steel welding and wood preservatives e.g. chromate copper arsenate 
(CCA) wood (He et al., 2007). In addition, electronic devices with flat panel displays and cathode-ray TV tubes contain significant amounts of chromium (Lim and Schoenung, 2010). Cr (VI) compounds are also present in cigarette smoke and automobile emissions (Benhard et al., 2005 and Lou et al., 2013). Moreover, significant levels of $\mathrm{Cr}$ (VI) have been found in drinking water sources (Sutton, 2010).

Hexavalent chromium Cr (VI) compounds are classified as class I human carcinogens (International Agency for Research on Cancer (IARC), 1990), based on increased incidences of lung cancers in animals and humans after inhalation exposures (the major route of exposure) and a large body of knowledge showing that they are mutagenic and genotoxic (NJDEP, 2006 and Seidler et al., 2013) .

p53 is a tumor suppressor gene whose product can act as a suppressor of transformation (Couture et al., 2013) and has been shown to be induced by DNA damage (Yan et al., 2013). p53 is known to play a key role in practically all types of human cancers, and the mutation or loss of the p53 gene can be identified in more than $50 \%$ of all human cancer cases worldwide (Tomasevic et al., 2010).

Small intestine is the primary site for great exposure to hazardous materials and its principal functions are subjected to the toxic effects of chemicals in food, water and other ingested materials. Under the current United States Environmental Protection Agency Guidelines for Carcinogen Risk Assessment (USEPA, 2005), oral exposure to Cr (VI) is likely to be carcinogenic to humans. Some investigators reported that antioxidants inhibit chemical carcinogenesis when the antioxidants are administered either prior or during carcinogenic changes (Srihari et al., 2008).

Proanthocyanidins, naturally occurring compounds widely found in fruits, vegetables, nuts, seeds, flowers and bark, are a group of polyphenolic bioflavonoids diverse in chemical structure, pharmacology and characteristics. The seeds of the grape (Vitis vinifera) are particularly rich source of proanthocyanidins (Nandakumar et al., 2008). Besides the free radical scavenging and antioxidant activity, grape seed proanthocyanidin extract (GSPE) exhibit vasodilatory, immunostimulating, antibacterial, cardioprotective, antiviral, anti-inflammatory, antiallergic and anti-tumoral activities (Mantena et al., 2006 and Tang et al., 2012 ).

To our knowledge there were no previous studies have shown the protective effect of GSPE on K dichromate toxicity in small intestine of adult male albino rats. Accordingly, the present study was carried out to investigate the antioxidant effect of GSPE against oxidative DNA damage induced by potassium dichromate on the small intestine of adult male albino rats through biochemical and microscopic study.

\section{Material and method}

\section{I- Chemicals}

1. Potassium dichromate $\left(\mathrm{K}_{2} \mathrm{Cr}_{2} \mathrm{O}_{7}\right)$ : Orange colored powder obtained from $\mathrm{El}$ Nasr
Pharmaceutical Chemicals Company (Cairo, Egypt).

2. Grape seed proanthocyanidin extract (GSPE): Powdered grape seed proanthocyanidin extract (GSPE) commercially known as Noxylife was obtained from Pharco Pharmaceuticals (Alexandria, Egypt).

\section{II- Experimental design}

This current work was carried out in Forensic Medicine \& Clinical Toxicology and Histology Departments in accordance to the guidelines of the Ethical Committee of Medical Research, Faculty of Medicine, Tanta University, Egypt.

This study was carried out on 40 adult male albino rats, their weight ranged from 150-200 $\mathrm{g}$. During the study the animals were kept in wire mesh cages with ad-libitum access to water. The room temperature was about $22-24{ }^{\circ} \mathrm{C}$ and the animals were exposed to 12:12 hours light dark cycles. Animals were allowed a two week pre-experimentation period to be acclimatized to the laboratory conditions.

The animals were randomly divided into 4 equal groups; all animals received their doses orally by syringe feeding method once daily for two months:

1. Group I (control group): received $0.2 \mathrm{ml}$ distilled water which is the diluting vehicle of potassium dichromate and GSPE.

2. Group II: (GSPE group): received $100 \mathrm{mg} / \mathrm{kg}$ GSPE prepared as $20 \mathrm{mg} / 0.2 \mathrm{ml}$ solution in distilled water (Das, 1999).

3. Group III: (K dichromate treated group): received $15 \mathrm{mg} / \mathrm{kg} \mathrm{K}$ dichromate prepared as $3 \mathrm{mg} / 0.3 \mathrm{ml}$ solution in distilled water (Krim et al., 2013). LD50 of K dichromate in rats is $80 \mathrm{mg} / \mathrm{kg}$ (Slooff, 1989).

4. Group IV: (protective group): received GSPE with potassium dichromate concomitantly (at the same dose and duration in group II and III).

\section{III- Methods}

Body weight was recorded at the beginning of the experiment of all studied groups and after 2 months. At the end of the experiment and after 6 hours fasting, the animals were anaesthetized by ether, and while the heart is still beating blood was collected on heparin via cardiac puncture. Plasma was separated and stored in aliquots at $-80^{\circ} \mathrm{C}$ till used for the assay of the levels of malondialdehyde (MDA) and total thiol level (T-SH).

Then all rats were sacrificed by decapitation, the abdomen was opened and pieces of small intestine were taken from duodenum $(2 \mathrm{~cm}$ distal to the pyloric sphincter), jejunum (10 cm distal to ligament of trites) and ileum ( $2 \mathrm{~cm}$ proximal to the ileocecal junction). Intestinal tissue was divided into three parts. The first part was used for histological assessment and immunohistochemistry for $\mathrm{p} 53$. The second part was used for scanning electron microscopy. The third part of intestinal specimens were washed three times with 
ice cold saline and blotted individually on ash-free filter paper, and weighted then homogenized separately with a potter-Elvenhjem tissue homogenizer. The tissue was homogenized in phosphate buffer saline (PBS) $10 \mathrm{mM} \mathrm{pH} 7.4$ for estimation levels of MDA and T-SH (Turpeenoja et al., 1988). Protein concentration for each homogenate was determined by the method of Lowry et al. (1951).

\section{Spectrophotometric assay}

\section{MDA level}

Oxidation of polyunsaturated fatty acids leads to lipid peroxidation (Valavanidis et al., 2006). The method described by (Ohkawa et al., 1979) depends on the reaction of MDA as an end product of lipid peroxidation with thiobarbituric acid producing thiobarbituric acid reactive substance (TBARS), a pink chromogen, which can be measured spectrophotometrically at $532 \mathrm{~nm}$, by commercial kit (Biodiagnostic, Egypt), the results were expressed as $\mathrm{nmol} / \mathrm{ml}$ or $\mathrm{nmol} / \mathrm{mg}$ protein for plasma and tissue respectively.

\section{T-SH content}

The total thiol status in the body is considered as major antioxidants in our body. Breifly, $100 \mu \mathrm{L}$ of plasma or tissue homogenate was added to reaction mixture containing $900 \mu \mathrm{L}$ of $2 \mathrm{mmol} \mathrm{Na}_{2}$ EDTA in 0.2 mol $\mathrm{Na}_{2} \mathrm{HPO}_{4}$ and $20 \mu \mathrm{L}$ of $10 \mathrm{mmol} 5$ ' 5' dithio-bis (2-nitrobenzoic acid) (DTNB) in $0.2 \mathrm{M} \mathrm{Na}_{2} \mathrm{HPO}_{4}$, incubated at room temperature for $5 \mathrm{~min}$ and absorbance was read at $412 \mathrm{~nm}$. Total thiol level was determined using molar extinction coefficient $1600 \mathrm{M}$ $1 \mathrm{Cm}-1$ and expressed as $\mathrm{nmol} / \mathrm{L}$ or $\mathrm{nmol} / \mathrm{mg}$ protein for plasma and tissue respectively (Motchnik et al., 1994)

\section{Histological study}

The intestinal specimens were washed with saline and fixed in phosphate-buffered formalin solution for $24 \mathrm{~h}$. Tissues were processed and embedded in paraffin wax by routine protocol. Five $\mu \mathrm{m}$ thick sections were mounted on slides and stained with hematoxylin and eosin. The sections were examined by Leica binocular light microscope with built in camera (Marilyn, 2008).

\section{Immunohistochemical study}

For immunohistomchemical study, five $\mu \mathrm{m}$ sections were mounted, dried and dewaxed in xylene. Rehydrated sections were then incubated with 3\% hydrogen peroxide in humidified boxes to block the endogenous activity of peroxidase. Microwaveassisted antigen retrieval was performed for 20 minutes. Sections were then incubated overnight at 4 $\mathrm{C}^{\mathrm{o}}$ with primary rabbit primary $\mathrm{p} 53$ antibody (Rabbit anti-human p53 monoclonal antibody, unconjugated, clone SP5. Lab Vision Catalog $\neq$ RM-9105-R7, ID: 149917). After washing with PBS (phosphate buffer solution), sections were incubated with biotinylated goat anti rabbit secondary antibody for 30 minutes and then with streptavidin peroxidase conjugate(Medical and Biological Laboratories Co. Ltd., Japan) for 30 minutes. Sections were then washed with PBS, and incubated with diaminobenzidine (DAB) chromogen
(Sigma) to detect immunoreactivity. Counterstaining was performed by Mayer's hematoxylin. The expression for p53 was localized to the nuclei of cells (Jackson and Blythe, 2008). Negative control was done using the same steps except that phosphate buffered saline was applied instead of the primary antibody (Marilyn, 2008).

\section{Scanning electron microscope}

For scanning electron microscopic examination (SEM), small pieces of small intestine were washed several times with saline and cleaned with a fine, hair brush. They were fixed in phosphate buffered $2.5 \%$ glutaraldehyde for 3-4 hr and post-fixed in phosphate buffered $1 \%$ osmium tetra oxide for $1 \mathrm{hr}$. The specimens were dehydrated in a graded series of ethanol and dried at a critical point using liquid $\mathrm{CO}_{2}$. The dried specimens were attached to the stubs and then coated with gold by coating apparatus coating SPI module -VAC/sputter coater (Bozzola and Russel, 1999). The coated specimens were examined directly in scanning electron microscope (JOEL, JSM5200LV) at the Faculty of medicine, Tanta University.

\section{Morphometric and image analysis}

This was done in three histological sections per animal. From each section ten randomly selected fields of wellorientated haematoxylin and eosin stained sections were evaluated to generate the quantitative data. The following parameters were counted; the number of intact villi and intact crypts per field (X200), villous height and crypt depth (X200) in $\mu \mathrm{m}$, were measured to estimate villus/crypt ratio. This was done using Leica light microscope with built in camera. The height of villi was measured from the tip of the villus to the villus-crypt junction. Villous height and crypt depth are direct representations of the intestinal environment and may be used as an indicator of intestinal health. The villus:crypt ratio is an indicator of the likely digestive and absorptive capacity of the small intestine (Zitnan et al., 2003).

Image analysis system was used to count the mean number of positive cells for $\mathrm{p} 53$ in the intestinal tissue of the different studied groups. The positive staining cells were observed under 400X magnifications. Ten non overlapping fields in slides of each animal of each group were examined.

\section{IV- Statistics}

Statistical presentation and analysis of the present study was conducted, using the mean, standard deviation by SPSS V.16. In view of the multiple measurements used and the variables involved, statistical analysis was by one way analysis of variance (ANOVA), with post-hoc test. $\mathrm{P}<0.05$ was considered significant.

\section{Results}

\section{I- Initial and final body weights (gm)}

Body weights were decreased significantly in rats received $\mathrm{K}$ dichromate only (group III) compared with other studied groups (group I, II, IV), while treatment with GSPE significantly improved this change in group 
IV (Table 1).

\section{II- Measurements of oxidant/ antioxidant status}

Table (2) shows a significant increase in MDA both in plasma and intestinal tissue in rats treated with $\mathrm{K}$ dichromate (group III) compared with other studied groups (group I, II, IV), and significant reduction in group IV on treatment with GSPE along with $\mathrm{K}$ dichromate. Moreover, there was a significant decrease in total thiol level both in plasma and intestinal tissue in $\mathrm{K}$ dichromate treated animals (group III) compared with the other studied groups, while treatment with GSPE significantly improved this change in group IV.

\section{III- Histological results}

Light microscopic examination of hematoxylin and eosin (H\&E) stained sections of small intestine of the first and second groups were similar and revealed normal intestinal wall. The mucosa showed well formed villi with a core of connective tissue covered with tall columnar entrerocytes having thick regular continuous brush border, acidophilic cytoplasm and basal vesicular nuclei. Many Goblet cells were also present between them. The villi of the duodenum are leaf like while those of the jejunum and ileum are finger like. The crypts of Leiberkuhn appeared as invaginations of the mucosa between the bases of the villi. The submuocsa and muscularis externa were seen normal. The duodenum was identified by presence of Brunner's glands in its submucosa (Figure 1), while ileum was identified by presence of large lymphatic follicles of Peyer's patches inside its lamina propria and extend to its submucosa (Figure 2).

Group III ( $\mathrm{K}$ dichromate treated group) revealed deleteriously damaged intestinal mucosa. The maximum damage was mainly detected in the duodenum that decreased gradually in the jejunum to be minimal in the ileum. These changes were in the form of epithelial hyperplasia as evidenced by increase number of enterocytes to become stratified rather than being simple with distortion, broadening and shortening of the villi together with wide sub epithelial edema under the tips of the villi (Figure 3). Epithelial desquamation and sloughing together with surface discontinuity were commonly observed. The lamina propria showed cellular infiltration and long crypts (Figure 4). Some areas of the intestinal mucosa showed loss of architecture and short irregular broad villi (Figure 5).

Examination of sections of group IV animals showed disappearance of most of histological changes. The villi and the crypts were more or less similar to the control group (Figure 6).

\section{Morphometric results}

The villous height showed statistically significant decrease, while crypt length displayed statistically significant increase in small intestine of group III animals in comparison to the control group. This was reversed in GSPE treated group (group IV) where no significant difference was observed in comparison to the control group. The ratio of villous height to crypt depth in the normal small intestine showed a mean of $3.10 \pm 0.31$ and $3.09 \pm 0.34$ in group I and II respectively. Potassium dichromate treated group showed significant reduction in the villus/crypt ratio with marked improvement on addition of GSPE in group IV.

The number of the villi and crypts were decreased in a statistically significant manner in $\mathrm{K}$ dichromate treated animals (group III ) in comparison to the other studied groups (group I, II, IV), while treatment with GSPE significantly improved these changes in group IV (Table 3).

\section{IV- Immunohistochemical results}

Immunostained sections of the control and GSPE treated groups (group I and II) showed similar results. They revealed absence of immuno reaction in the mucosa of the small intestine (Figure 7). On the other hand, $\mathrm{K}$ dichromate treated group (group III) showed prominent increase in the number and intensity of p53 positive cells in the intestinal epithelium covering the villi and those lining crypts (Figure 8). The p53 expression was localized to the nuclei of small intestinal cells as indicated by the brown nuclei in figure (8). The reaction was observed prominently in the duodenum and decreased gradually in the jejunum and ileum. The intestinal mucosa of group IV showed decrease in the number and intensity of immunostained intestinal epithelial nuclei (Figure 9).

\section{Morphometric results}

Table (4) shows comparative statistics of p53 positivity in all studied groups. The highest mean positivity was detected in group III ( $\mathrm{K}$ dichromate treated animals) compared to group I (control group) and group II (GSPE treated animals).There was significant improvement on administration of GSPE in group IV. There was a statistically significant difference among the four groups $(\mathrm{p}<0.05)$.

\section{V-Scanning electron microscope}

Small intestine of control group (group I) of group II showed multiple uniform villi having hump like appearance. They were leaf like in the duodenum and finger like in the jejunum and ileum (Figure10). The top surface of the columnar epithelium showed hexagonal appearance with close approximation of the cells to each other and Goblet cells were seen as electron lucent variable sized ballooned structure inbetween (Figure, 11).

The mucosa of small intestine of potassium dichromate treated group revealed wide diffuse affection and multiple erosion of their surface and disruption of their villi in association with focal areas of complete loss of the villi (Figure12). Some villi showed desquamation of their epithelium and appeared as scale like (Figure13). The top surface of the villi displayed depletion of the Goblet cells and shrinkage of the columnar epithelial cells with widening of the intercellular space (Figure14). The maximum damage was in the duodenum followed by jejunum and lastly the ileum. The mucosa of GSPE treated group displayed similar findings like that of the control group except for few localized areas which showed disrupted villi (Figure15). 
Table 1: ANOVA one way statistical analysis with post-hoc test of initial and final body weights among different studied groups.

\begin{tabular}{|c|c|c|c|c|c|c|}
\hline \multirow{2}{*}{ Parameter/group } & \multirow{2}{*}{$\begin{array}{c}\text { Group I }^{\mathrm{a}} \\
(\mathrm{n}=\mathbf{1 0})\end{array}$} & \multirow{2}{*}{$\begin{array}{c}\text { Group II }^{b} \\
(\mathbf{n}=\mathbf{1 0})\end{array}$} & \multirow{2}{*}{$\begin{array}{c}\text { Group III }{ }^{\mathrm{c}} \\
(\mathrm{n}=\mathbf{1 0})\end{array}$} & \multirow{2}{*}{$\begin{array}{c}\text { Group IV }^{\mathrm{d}} \\
(\mathbf{n}=\mathbf{1 0})\end{array}$} & \multicolumn{2}{|c|}{ ANOVA } \\
\hline & & & & & $\mathbf{F}$ & $\mathbf{P}$ \\
\hline Initial weight (gm) & $168.1+15.6$ & $171.7+15.6$ & $167.6+13.8$ & $168.9+14.7$ & 0.336 & 0.225 \\
\hline Final weight (gm) & $247.7 \pm 15.3^{\mathrm{cd}}$ & $251.4+15.2^{\mathrm{cd}}$ & $205.5 \pm 8.10^{\text {abd }}$ & $235+13.8^{a b c}$ & 6.335 & $0.005 *$ \\
\hline
\end{tabular}

$a$-d: significant difference between groups at $p<0.05^{*}$. Data are mean \pm standard deviation of 10 rats of each group.

Table 2: ANOVA one way statistical analysis with post-hoc test of MDA level and T-SH content among the different studied groups .

\begin{tabular}{|c|c|c|c|c|c|c|c|}
\hline \multirow{2}{*}{\multicolumn{2}{|c|}{ Parameter group }} & \multirow{3}{*}{$\begin{array}{c}\begin{array}{c}\text { Group I }^{\mathbf{a}} \\
(\mathbf{n}=\mathbf{1 0})\end{array} \\
2.82 \pm 0.02^{\mathrm{cd}}\end{array}$} & \multirow{3}{*}{$\begin{array}{c}\begin{array}{c}\text { Group II }^{b} \\
(\mathbf{n}=\mathbf{1 0})\end{array} \\
2.82 \pm 0.03^{\mathrm{cd}}\end{array}$} & \multirow{3}{*}{$\begin{array}{c}\begin{array}{c}\text { Group III }^{\mathbf{c}} \\
(\mathbf{n}=\mathbf{1 0})\end{array} \\
4.52+0.34^{\mathrm{abd}}\end{array}$} & \multirow{3}{*}{$\begin{array}{c}\begin{array}{c}\text { Group IV } \\
(\mathbf{n}=\mathbf{1 0})\end{array} \\
3.01+0.15^{\mathrm{abc}}\end{array}$} & \multicolumn{2}{|c|}{ ANOVA } \\
\hline & & & & & & $\mathbf{F}$ & $\mathbf{P}$ \\
\hline \multirow[b]{2}{*}{$\begin{array}{l}\text { MDA } \\
\text { level }\end{array}$} & Plasma $(\mathrm{nmol} / \mathrm{ml})$ & & & & & 3.326 & $0.024 *$ \\
\hline & $\begin{array}{l}\text { Intestinal tissue } \\
\text { (nmol/mg protein) }\end{array}$ & $2.61 \pm 0.07^{\mathrm{cd}}$ & $2.62+0.07^{\mathrm{cd}}$ & $4.94+0.10^{\mathrm{abd}}$ & $2.98+0.12^{\mathrm{abc}}$ & 5.632 & $0.019 *$ \\
\hline \multirow{2}{*}{$\begin{array}{l}\mathrm{T}-\mathrm{SH} \\
\text { content }\end{array}$} & Plasma $(\mathrm{nmol} / \mathrm{ml})$ & $12.2 \pm 0.12 \mathrm{c}$ & $12.3 \pm 0.12 \mathrm{c}$ & $8.45 \pm 0.20^{\mathrm{abd}}$ & $11.3 \pm 0.40 \mathrm{c}$ & 1.225 & $0.012 *$ \\
\hline & $\begin{array}{l}\text { Intestinal tissue } \\
\text { (nmol/mg protein) }\end{array}$ & $15.1 \pm 0.22 \mathrm{c}$ & $15.1 \pm 0.17 \mathrm{c}$ & $9.15+0.32^{\mathrm{abd}}$ & $13.7 \pm 0.65 \mathrm{c}$ & 3.412 & $0.045^{*}$ \\
\hline
\end{tabular}

$a-d$ : significant difference between groups at $p<0.05 *$. Data are mean土 standard deviation of 10 rats of each group.

Table 3: ANOVA one way statistical analysis with post-hoc test of the morphometric results (villous height, crypt depth, villus/crypt ratio and number of villi and crypts) among all studied groups.

\begin{tabular}{|c|c|c|c|c|c|c|}
\hline \multirow{2}{*}{ Parameter/group } & \multirow{2}{*}{$\begin{array}{c}\text { Group I }^{\mathrm{a}} \\
(\mathbf{n}=\mathbf{1 0})\end{array}$} & \multirow{2}{*}{$\begin{array}{c}\text { Group II }^{b} \\
(n=10)\end{array}$} & \multirow{2}{*}{$\begin{array}{c}\text { Group III }^{\mathrm{c}} \\
(\mathrm{n}=10)\end{array}$} & \multirow{2}{*}{$\begin{array}{c}\text { Group IV } \\
(\mathbf{n}=\mathbf{1 0})\end{array}$} & \multicolumn{2}{|c|}{ ANOVA } \\
\hline & & & & & $\mathbf{F}$ & $\mathbf{P}$ \\
\hline Villous height $(\mu \mathrm{m})$ & $258.3+31.1^{\mathrm{cd}}$ & $255.2 \pm 27.7^{\mathrm{cd}}$ & $155.3 \pm 53.1^{\mathrm{abd}}$ & $231.9 \pm 27.6^{\mathrm{abc}}$ & 4.674 & $0.010 *$ \\
\hline Crypt depth $(\mu \mathrm{m})$ & $83.1+4.50^{\mathrm{c}}$ & $83.5 \pm 7.82^{c}$ & $124.8 \pm 16.3^{\text {abd }}$ & $80.3 \pm 5.36^{\mathrm{c}}$ & 3.951 & $0.015^{*}$ \\
\hline $\begin{array}{l}\text { Villous/crypt (V/C) } \\
\text { ratio }\end{array}$ & $3.10 \pm 0.31^{\mathrm{c}}$ & $3.09 \pm 0.34^{\mathrm{c}}$ & $1.26+0.45^{\mathrm{abd}}$ & $2.90+0.43^{\mathrm{c}}$ & 3.448 & $0.030 *$ \\
\hline Number of villi & $20.4 \pm 2.67^{\mathrm{cd}}$ & $18.8 \pm 2.48^{\mathrm{cd}}$ & $10+3.33^{\mathrm{abd}}$ & $16.2 \pm 4.77^{\mathrm{abc}}$ & 6.357 & $0.024 *$ \\
\hline Number of cypts & $28.8+9.6^{\mathrm{cd}}$ & $29.4+10.8^{\mathrm{cd}}$ & $17.4 \pm 7.10^{\mathrm{abd}}$ & $25.8 \pm 7.3^{a b c}$ & 4.124 & $0.019 *$ \\
\hline
\end{tabular}

$a-d$ : significant difference between groups at $p<0.05^{*}$. Data are mean+ standard deviation of 10 rats of each group.

Table 4: ANOVA one way statistical analysis with post-hoc test of p53 positivity in all studied groups

\begin{tabular}{|c|c|c|c|c|c|c|}
\hline \multirow{2}{*}{$\begin{array}{c}\text { Parameter } \\
\text { group }\end{array}$} & \multirow{2}{*}{$\begin{array}{c}\text { Group I }^{\mathrm{a}} \\
(\mathrm{n}=\mathbf{1 0})\end{array}$} & \multirow{2}{*}{$\begin{array}{c}\text { Group II }^{b} \\
(n=10)\end{array}$} & \multirow{2}{*}{$\begin{array}{c}\text { Group III } \\
(n=10)\end{array}$} & \multirow{2}{*}{$\begin{array}{c}\text { Group IV } \\
(n=10)\end{array}$} & \multicolumn{2}{|c|}{ ANOVA } \\
\hline & & & & & $\mathbf{F}$ & $\mathbf{P}$ \\
\hline p53 & $1.20 \pm 0.63^{\mathrm{cd}}$ & $1.60 \pm 1.09^{\mathrm{cd}}$ & $45.4 \pm 13.6^{\mathrm{abd}}$ & $1.70 \pm 1.13^{\mathrm{abc}}$ & 5.223 & 0.009* \\
\hline
\end{tabular}

$a$-d: significant difference between groups at $p<0.05^{*}$. Data are mean+ standard deviation of 10 rats of each group.

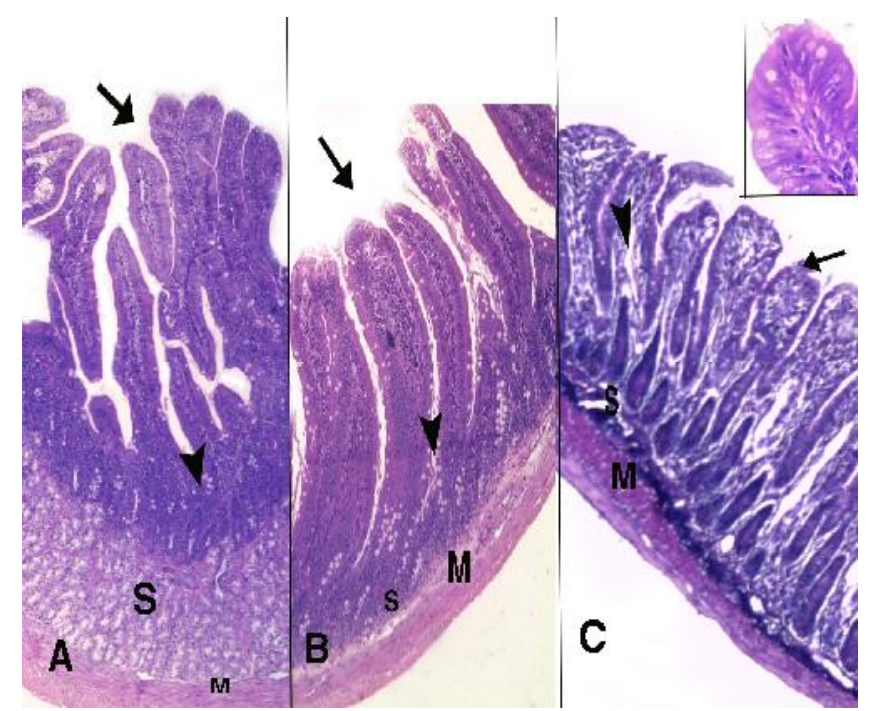

Figure 1: Photomicrograph of section small intestine of control group showing; A (doudenum), B (jejunum) and $C$ (ileum) with normal villi $(\rightarrow$ ) and crypts $(\rightarrow)$ with normal narrow submucosa (S) resting on muscularis externa (M) (H\&E X200). Notice Brunner's glands in submucosa of duodenum (A) and the inset (C) showing part of the villous with simple columnar absorptive epithelium and goblet cell. (H\&E X1000). 


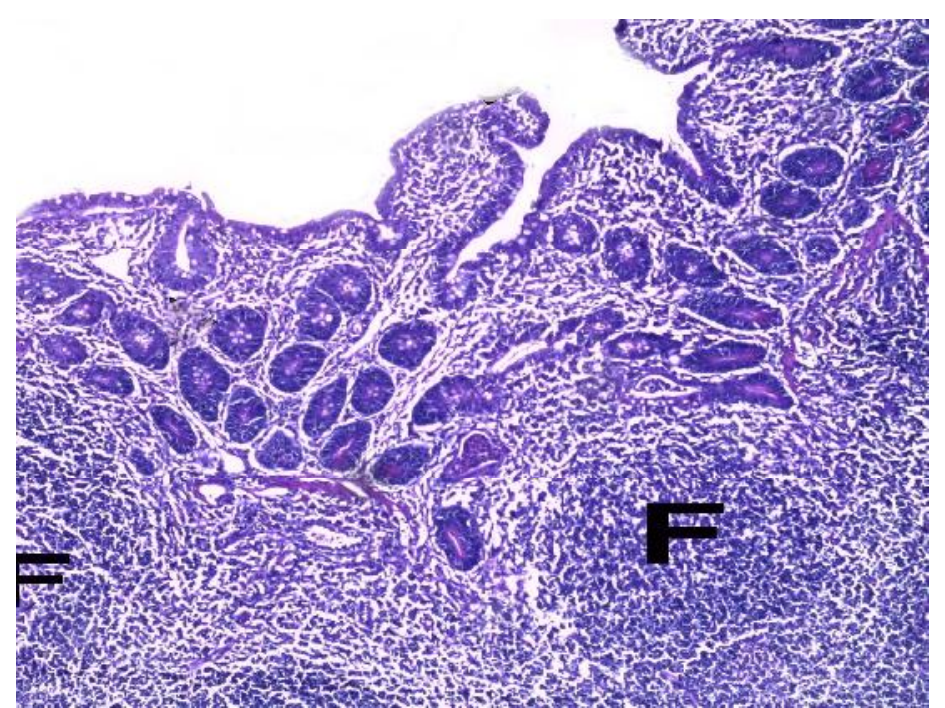

Figure 2: Photomicrograph of intestinal section of ileum of potassium dichromate treated group (Group III) showing large sized reactive lymphatic follicle of the peyer's patches in the submucosa extending to the lamina propria (F). (H\&E X400).

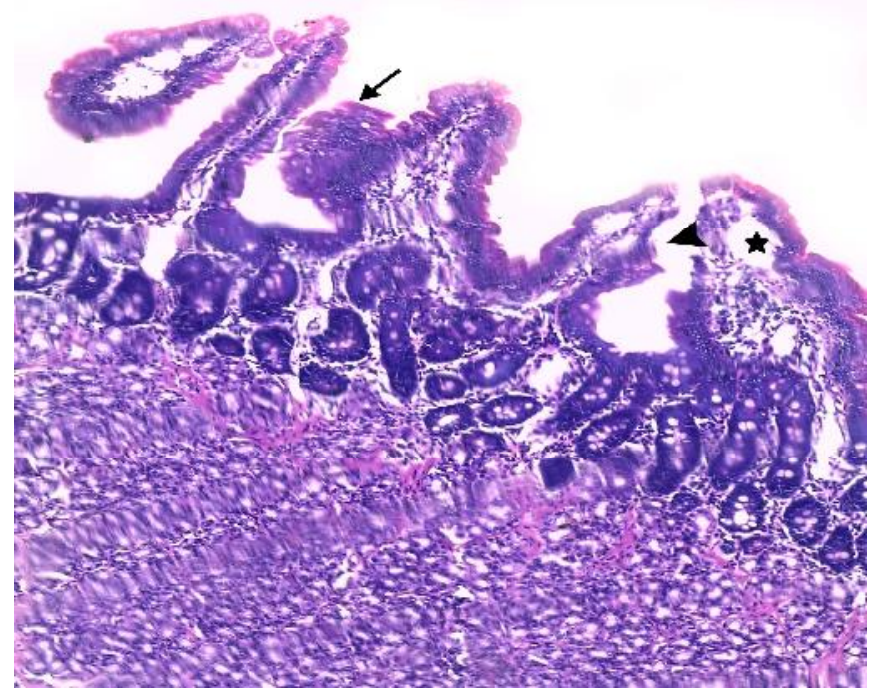

Figure 3: Photomicrograph of intestinal section (duodenum) of potassium dichromate treated group (Group III) showing epithelial hyperplasia $(\rightarrow)$ with distortion and shortening of the villi $(\rightarrow)$. Notice wide subepithelial edema under the tips of the villi (*). (H\&E X200).

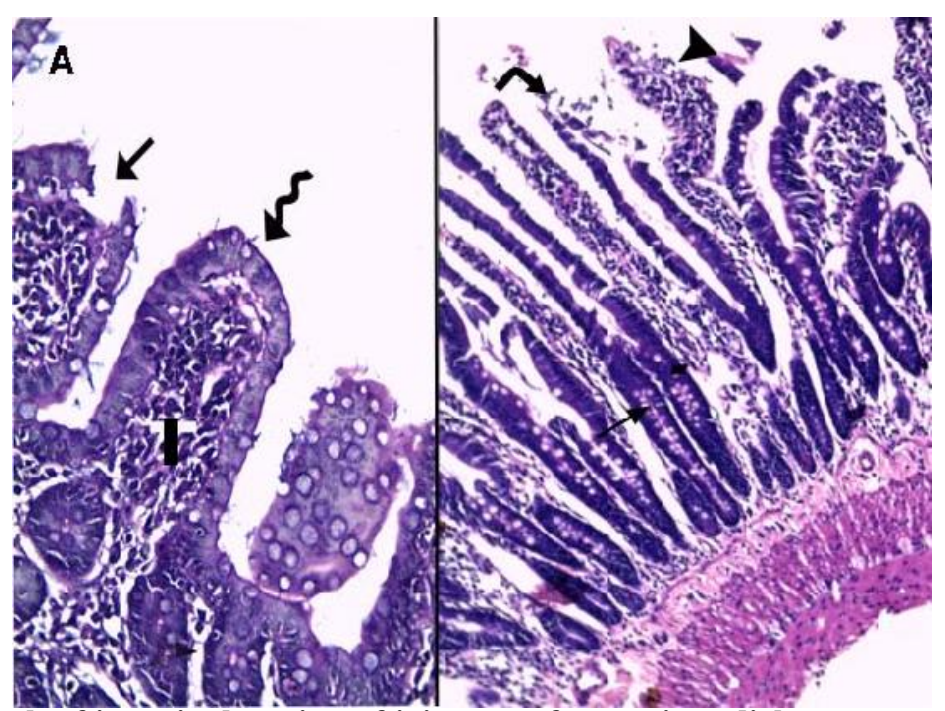

Figure 4: Photomicrograph of intestinal section of jejunum of potassium dichromate treated group (Group III); A: showing surface discontinuity $(\rightarrow$ ), cellular infiltration (I) and shortening of the villi (wavy arrow) (H\&E X400). B: showing desquamation $(\triangleright)$ and distorted villi (curved arrow) and long crypts ( $\rightarrow$ ). (H\&E X200). 


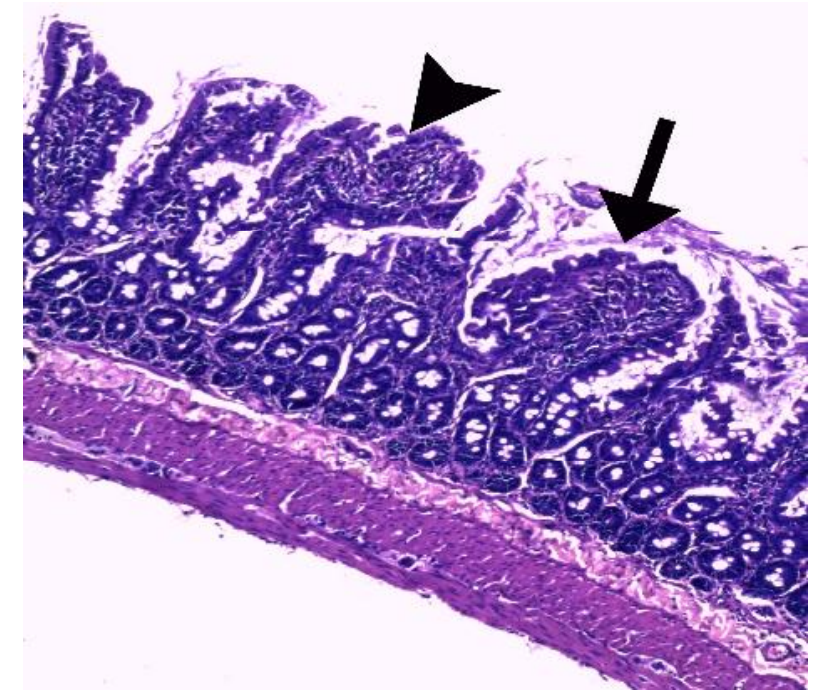

Figure 5: Photomicrograph of intestinal section of jejunum of potassium dichromate treated group (Group III) showing loss of architecture and irregular $(\rightarrow)$ and short broad villi $(\rightarrow)$. (H\&E X200).

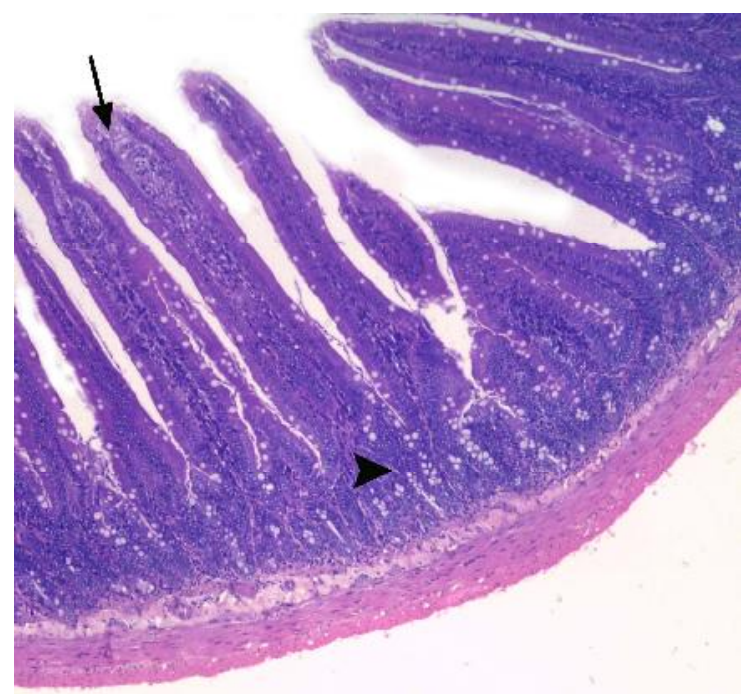

Figure 6: Photomicrograph of intestinal section of the protective group (group IV) showing mucosa of jejunum with apparently normal villi $(\longrightarrow)$ and crypts $(\rightarrow)$. (H\&E X200).

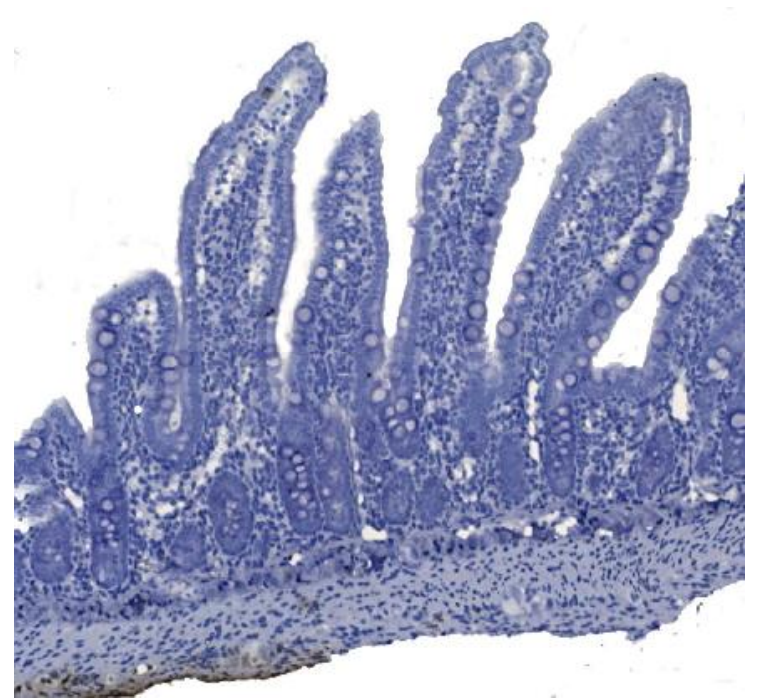

Figure 7: Photomicrograph of small intestine (jejunum) of control group showing negative immunoreaction for p53 in the nuclei of the cells covering the villi. (p53 immunostaining X200). 


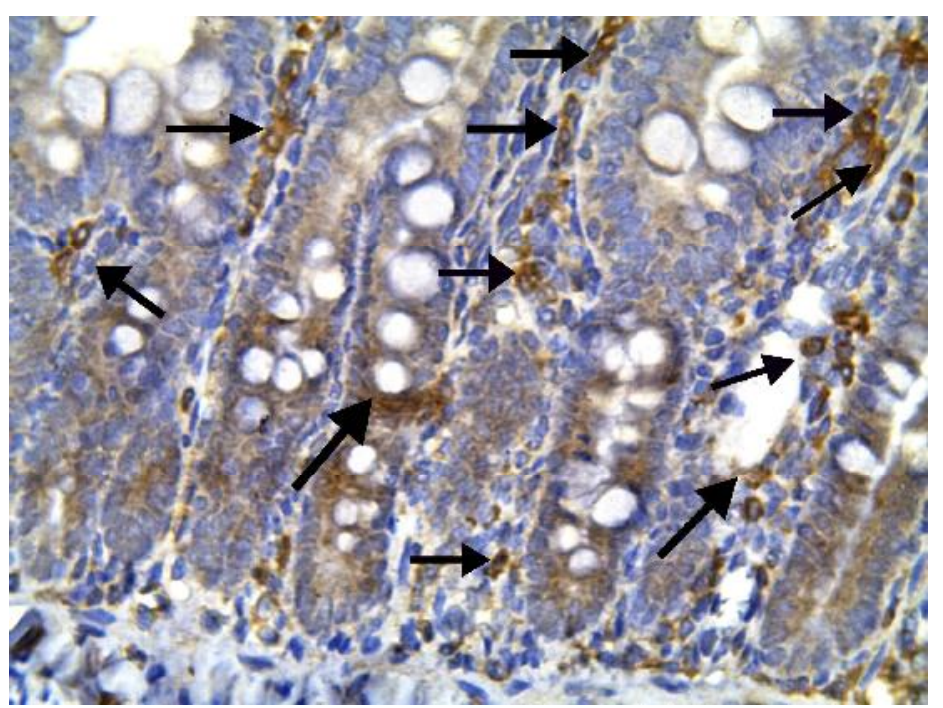

Figure 8: Photomicrograph of small intestine (jejunum) of potassium dichromate treated group (Group III) showing many positively immunostained nuclei for $\mathrm{p53}$ in the cells covering the villi or lining the crypts of Lieberkhun $(\rightarrow)$. (p53 immunostaining X400).

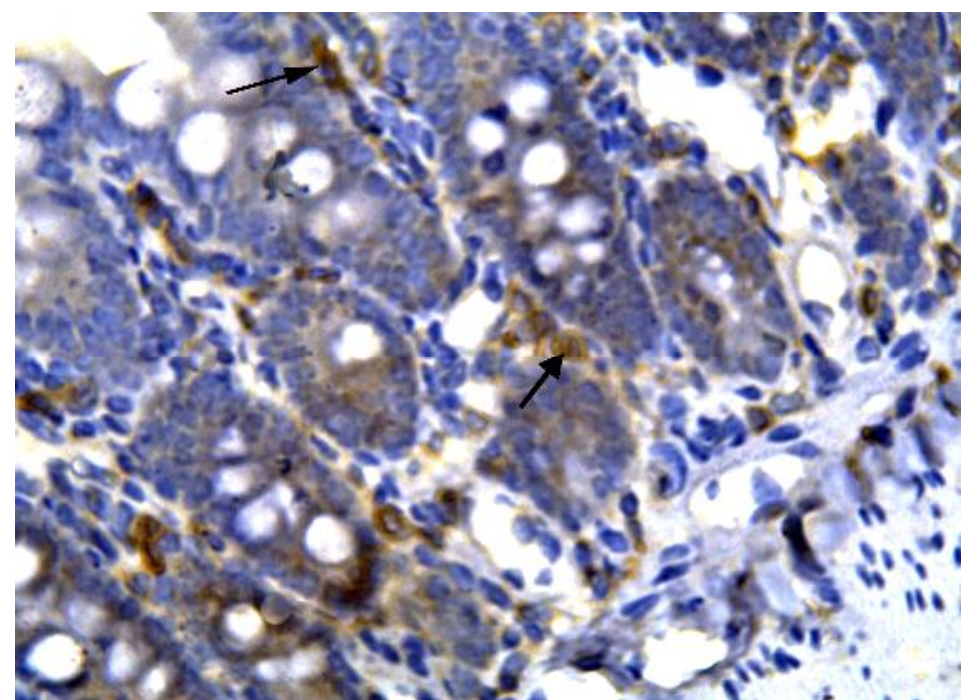

Figure 9: Photomicrograph of jejunum of the protective group (GroupIV) showing decrease in the number of positively immunostained nuclei for p53 in the cells covering the villi or lining the crypts of Lieberkhun $(\rightarrow)$. (p53 immunostaining X400).
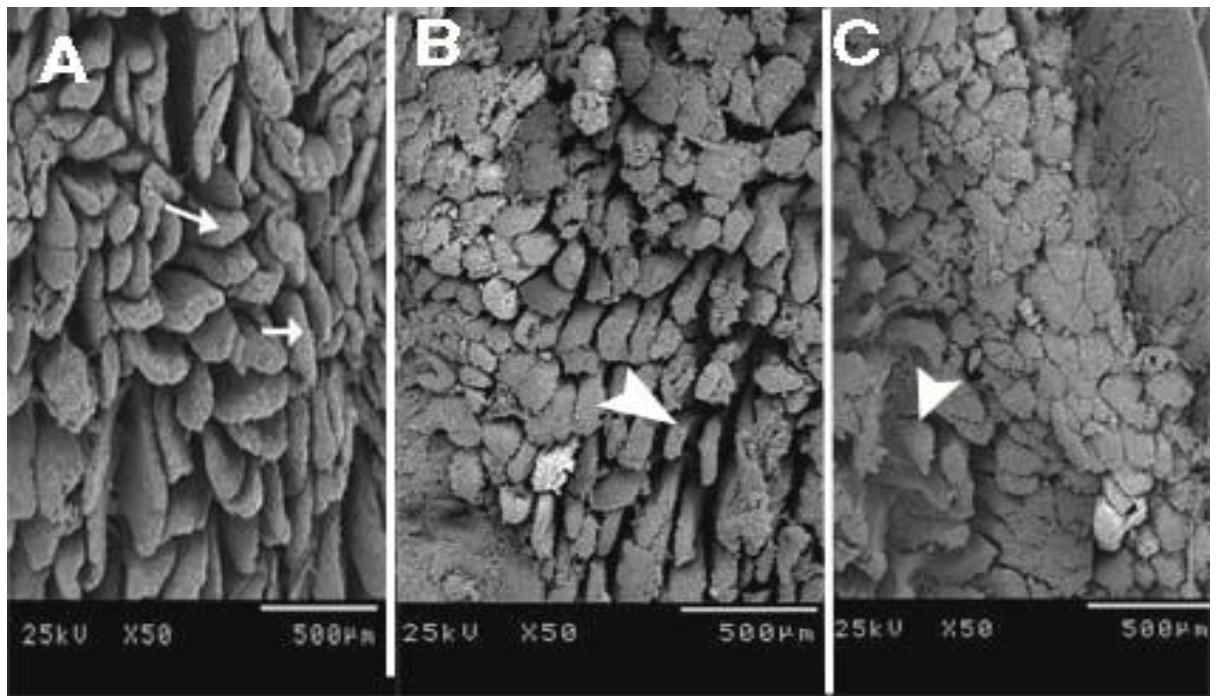

Figure 10: Scanning electron micrograph of small intestine of control group (Group I) showing multiple uniform villi having hump like appearance. Notice leaf like villi of the duodenum $(A)(\rightarrow)$, and finger like villi in the jejunum (B) and ileum (C) ( $)$. (SEM X50). 


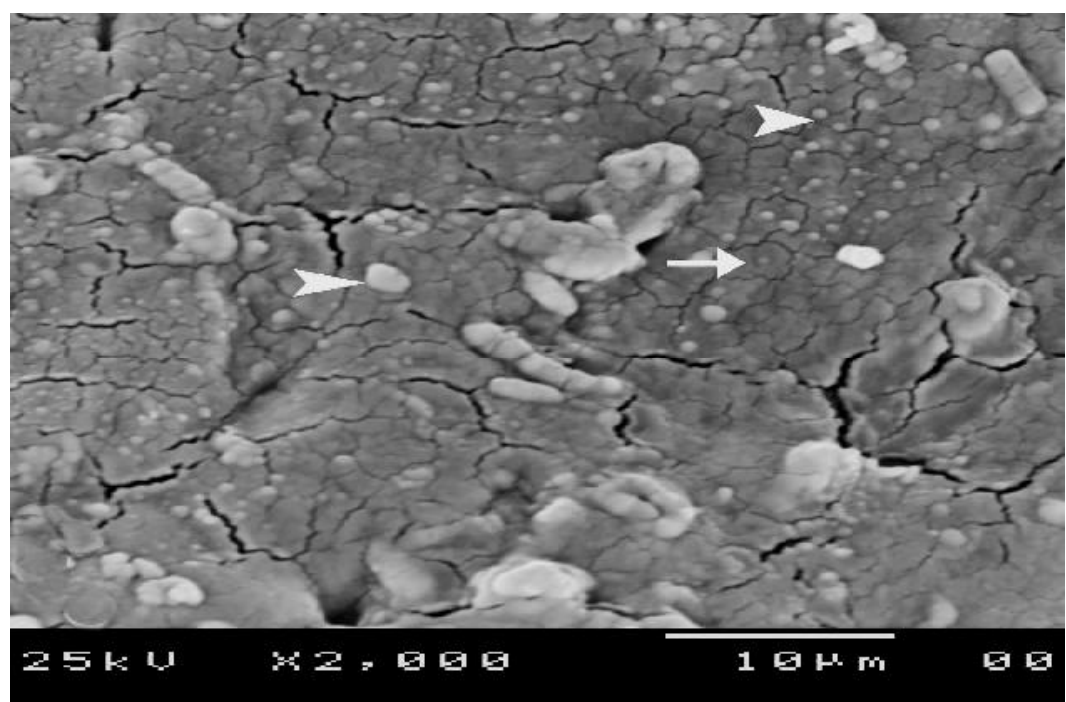

Figure 11: Scanning electron micrograph of duodenum of control group (Group I) showing hexagonal appearance of the top surface of the columnar epithelium $(\rightarrow)$ with Goblet cells in-between ( $D$ ). Notice close approximation of the cells to each other. (SEM X2000).

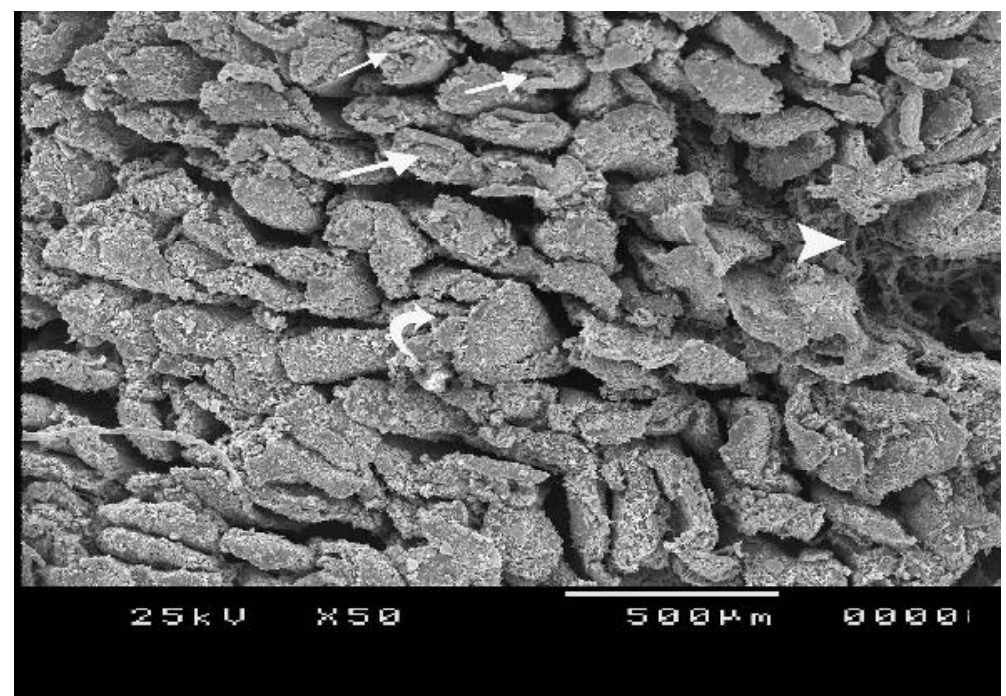

Figure 12: Scanning electron micrograph of duodenum of potassium dichromate treated group (Group III) showing disruption of the villi (curved arrow) in association with erosion of their surface $(\rightarrow)$ and loss of the others ( $)$. (SEM X50).

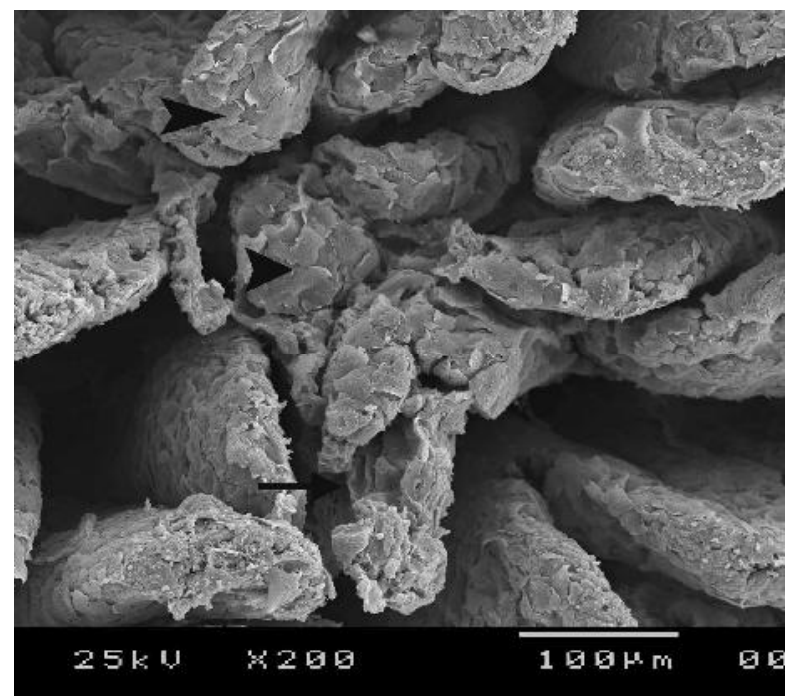

Figure 13: Scanning electron micrograph of duodenum of potassium dichromate treated group (Group III) showing disruption of the villi $(\rightarrow)$ with desquamation of the covering epithelium having scale like appearance (D). (SEM X200). 


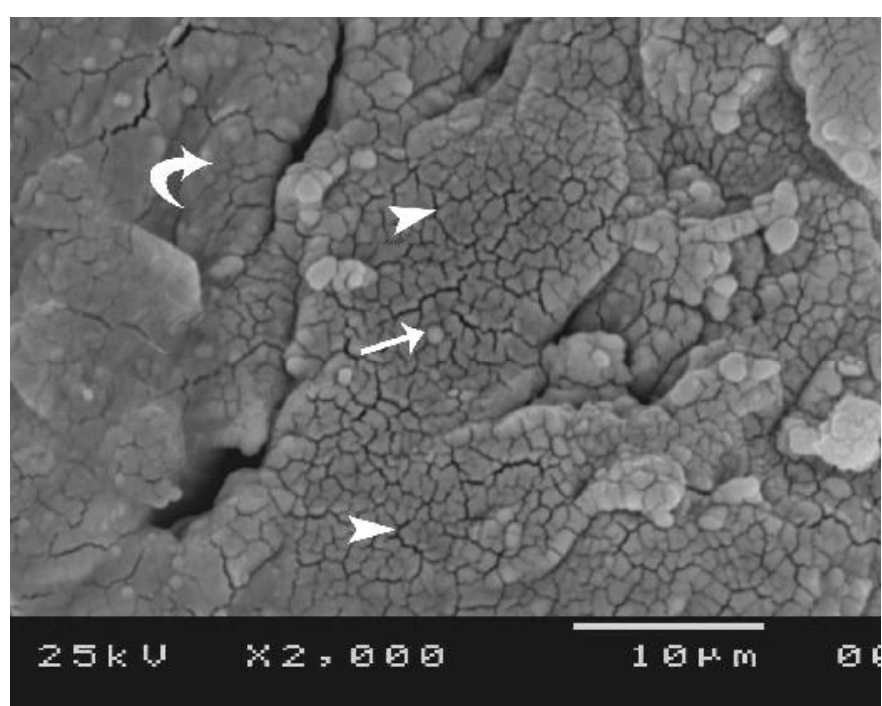

Figure 14: Scanning electron micrograph of duodenum of potassium dichromate treated group (Group III) showing depletion of the Goblet cells $(\rightarrow)$. Notice shrinkage of the columnar epithelium cells with widening of the intercellular space $(\checkmark)$ in comparison to the nearby normal area (curved arrow). (SEM X2000).

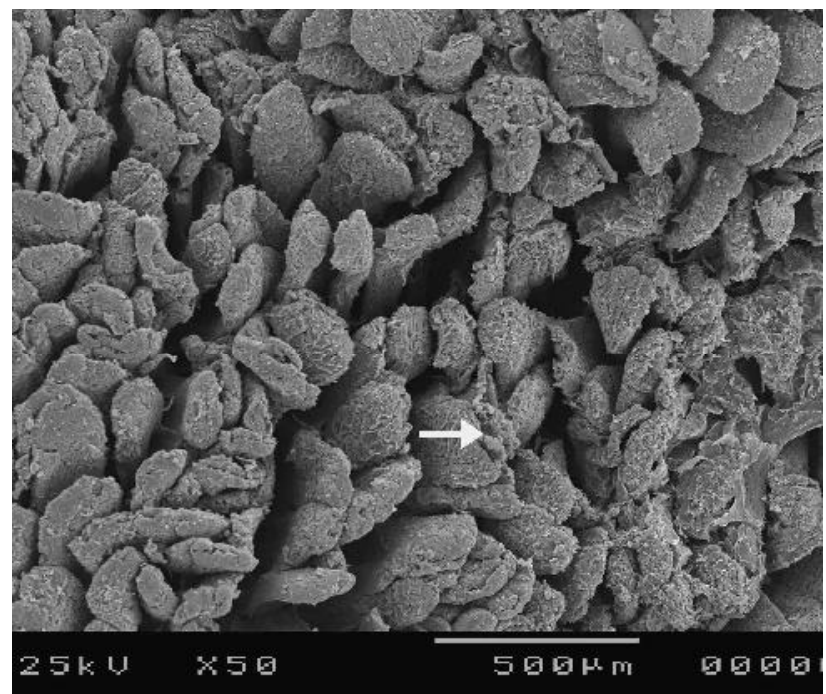

Figure 15: Scanning electron micrograph of duodenum of the protective group (Group IV) showing multiple uniform villi having normal appearance like that of the control group but few of them still showing erosion of their surface $(\rightarrow)$ (SEM X50).

\section{Discussion}

Chromium usage is increasing worldwide. Oral exposure to $\mathrm{Cr}$ (VI) in animals and humans causes various health hazards ( $\mathrm{Li}$ et al., 2011). The current study evaluated the toxic effects of $\mathrm{K}$ dichromate in the dosage of $15 \mathrm{mg} / \mathrm{kg} /$ day orally on the small intestine of adult male albino rats through biochemical and microscopic examination and the possible protective effect of grape seed proanthocyanidin extract (GSPE) in a dosage of $100 \mathrm{mg} / \mathrm{kg} /$ day orally.

In the present study, there was a significant decrease in body weight in $\mathrm{K}$ dichromate treated rats (group III) compared to the other studied groups with significant improvement in group IV on administration of GSPE along with Cr (VI). This was in agreement with National Toxicology Program (NTP) $(2007,2008)$ where body weight of rats received $\mathrm{Cr}$ (IV) in water was decreased more than $10 \%$ relative to controls due to unpalatability of water containing sodium dichromate dehydrate and diminished general and oral health in rats because of development of squamous cell carcinoma of the oral mucosa (buccal and tongue regions). Similarly, Kumar and Roy (2009) found that chromium induced a decrease in body weight gain, liver weight, and liver/body ratio. This finding might be also attributed to the mucosal structural damage as evidenced by light and scanning electron microscope.

The current study revealed that the level of MDA in plasma and intestinal tissue of chromiumtreated rats (group III) was significantly higher than the control group. This may reflect that the mechanism of $\mathrm{Cr}$ toxicity is possibly mediated by oxidative stress when the production of reactive oxygen species (ROS) overwhelms antioxidant defense mechanism (Valko et al., 2005). Free radicals trigger cell damage through binding to cellular macromolecules, particularly membrane lipids and polyunsaturated fatty acids in the endoplasmic reticulum (Naik and Panda, 2007). These results were in line with Bagchi et al. (1995) who 
demonstrated that rats received $\mathrm{Cr}(\mathrm{VI})$ orally in water developed hepatic mitochondrial and microsomal lipid peroxidation (LPO), as well as enhanced excretion of urinary lipid metabolites including malondialdehyde (MDA). These results also coincided with Ambreen et al. (2012) and Khan et al. (2012) who reported that occupationally exposed workers to $\mathrm{Cr}$ (IV) show significantly higher concentration of MDA compared with unexposed population, and decreased level of glutathione (GSH) which is a major endogenous antioxidant.

The current study revealed a significant decrease in total thiol level both in plasma and intestinal tissue in $\mathrm{Cr}$ (VI) treated rats compared to control group Total thiols are the major and most efficient antioxidants that have the ability to react with free radicals and protect against reactive oxygen species- induced damage (Muttigi et al., 2009).. Medeiros et al. (2003) attributed decreased value of total thiol in $\mathrm{Cr}$ (VI) exposed workers to its involvement in the detoxification, inhibition of lipid peroxidation by scavenging free radicals or as an outcome of the increased participation of Glutathione (GSH) in stable DNA-protein crosslink adduct formation. Total thiol depletion impairs the cell's defense against the toxic actions of reactive oxygen species (ROS) and might lead to cell injury and death.

In the current study, there was significant improvement in malondialdehyde (MDA) and thiol levels in group IV as rats were treated with GSPE concomitantly with K dichromate. Ariga, (2004) proved the powerful antioxidant capacity of GSPE and its predominance over vitamin $\mathrm{C}$ and $\mathrm{E}$.

The present study demonstrated that potassium dichromate induced structural alterations in the mucosa of the small intestine especially the duodenum, followed by jejunum and lastly the ileum. Ileum was minimally affected by the toxic effect of the chromium because $\mathrm{Cr}$ (VI) absorption decreases distally through small intestine due to reduction of $\mathrm{Cr}$ (VI) to $\mathrm{Cr}$ (III) in the intestinal lumen and/or differences in the relative absorption of chromium in the intestinal segments. Additionally, the presence of large sized reactive lymphatic follicles of Payer's patches may share in providing protection to the ileum (Kirman et al., 2012).

All these changes were attributed to that $\mathrm{Cr}$ (VI) is absorbed by villous enterocytes and reduced to $\mathrm{Cr}$ (III) intracellularly leading to generation of oxygen radicals (O'Brien et al., 2003 and Valko et al., 2006). Reactive oxygen metabolites (ROMs) such as singlet oxygen $\left(\mathrm{O}_{2}\right)$, superoxide anion $\left(\mathrm{O}_{2}\right)$, hydroxyl radical $\left(\mathrm{OH}^{-}\right)$, and hydrogen peroxide $\left(\mathrm{H}_{2} \mathrm{O}_{2}\right)$ are involved in the initiation and promotion of carcinogenesis (Ray et al., 2000). Cr (III) has been shown to interact directly with DNA and other macromolecules to induce chromosomal alterations and mutational changes (Sen et al., 2010).

Blunt and short villi observed in the present study in association with elongation of the crypts were attributed by Kirman et al. (2012) to the increased number of crypt enterocytes but this increase was insufficient to maintain the normal length and structure of healthy intestinal villi. Gao et al. (2002) explained that pathophysiology of villus degeneration through inhibition of the de novo purine synthesis and thymidine kinase in the salvage pathway of pyrimidine synthesis in crypt cells of the small intestine. This will suppress proliferation and differentiation of small intestinal epithelial cells which occurred in the crypt. The crypt cells, which are rapidly generated, migrate to the villus tip, and the replacement of the intestinal epithelium is completed in 3 days in humans and in 2 days in rats. The suppression of proliferation and differentiation of the epithelial cells would reduce the migration of the epithelial cells along the crypt-villus axis (Verburg et al., 2000).

The current study revealed that localized areas of the intestinal mucosa, presented hyperplasia of the epithelium as evidenced by increased number of enterocytes to become stratified rather than being simple. All these changes were associated with significant decrease in villus/crypt ratio and the number of villi and crypts. These results were partially agreed with NTP (2007) and NTP (2008) studies that reported the presence of diffuse hyperplasia which was significantly increased in all groups treated with $\mathrm{Cr}$ (VI) in a dose-dependent manner and was characterized by short, broad and blunt villi and by elongated crypts that contained increased numbers of epithelial cells and mitotic figures in female mice but not in female or male rats. Such effects are a nonspecific response to various types of injuries, and can be associated with either hyperproliferation or hypoproliferation of crypt enterocytes (Serra and Jani, 2006).

Thompson et al. (2011) hypothesized a plausible mode of action of $\mathrm{K}$ dichromate for development of the intestinal tumors that includes: saturation of the reductive capacity of the upper gastrointestinal (GI) tract, absorption of $\mathrm{Cr}$ (VI) into the intestinal epithelium, oxidative stress and inflammation, cell proliferation, direct and/or indirect DNA modification, and mutagenesis.

p53 is a major "guardian of the genome" (Louwen and Yuan, 2013). The biological consequences of p53 activity include cell-cycle regulation, induction of apoptosis, development, differentiation, gene amplification, DNA recombination, chromosomal segregation, and cellular senescence (Pietsch et al., 2008 and Menendez et al., 2009). The p53 protein normally has a short half-life within the cell but it is markedly prolonged after missense mutation and deletions. Mutations in the DNA binding region account for $80 \%$ of point mutations and subsequently lead to the greatest decrease in p53 function. Missense mutations of p53 lead to accumulation of protein and nuclear overexpression as demonstrated by various immunohistochemical techniques (Esrig et al., 1993).

In the current study, there was a significant increase in the number of p53 positive cells in the intestinal tissue of group III animals which received $\mathrm{K}$ dichromate in comparison to control group. This coincided with Hill et al. (2008) and Banu et al. (2011) who detected increase in the total p53 protein and p53 phosphorylation in human colon carcinoma cells and 
ovarian granulosa cells of chromium treated SpragueDawley rats. Arakawa et al. (2012) also found mutation of p53 gene in Cr (VI)-treated human lung cells due to induction of oxidative DNA damage through $\mathrm{Cr}(\mathrm{V})$ intermediate.

Prolonged and continued exposure to chromium would induce oxidative DNA damage mainly by $\mathrm{Cr}$ (III) that triggers p53 over-expression and mutagenesis which contribute to carcinogenesis (Arakawa et al., 2006). Chromium III binds directly to DNA and produces stable DNA-chromium complexes, DNA strand breaks, DNA-DNA cross links, and DNAprotein cross links (Thompson et al., 2012). However, other studies showed an involvement of the oxidative damage pathway in the gentoxicity of chromium in occupationally exposed individuals (Goulart et al., 2005 and Nickens et al., 2010). Cr (VI) compounds may be mutagenic, as it was reported to cause chromosomal aberrations and increase in sister chromatid exchanges in lymphocytes from chromate production workers (Wise et al., 2010 and Sellappa et al., 2011). Xiao et al. (2013) reported that p53 expression is correlated with the $\mathrm{Cr}$ (VI)-induced increase in DNA protein cross-links (DPCs) which appears to be the direct and primary genotoxic effect of Cr (VI) exposure.

The results of the current study were in agreement with Izzotti et al. (1998) who reported an increase in 8-Oxo-2'-deoxyguanosine (8-oxo-dG), which is one of the major products of DNA oxidation, in the rodent lung after intra tracheal instillation of sodium dichromate dihydrate (SDD). Oxidative stress and stimulation of apoptosis induced by potassium dichromate enhance breakdown of the cytoskeleton. This explained the morphological features seen in the present study by scanning electron microscope such as depletion of goblet cells, shrinkage of the epithelial cells and widening of the intercellular spaces with frequent desquamation

The current study demonstrated marked improvement of histological appearance of small intestine, number of villi and crypts and villous/crypt ratio in group IV due to treatment of rats with GSPE along with $\mathrm{Cr}$ (VI). Additionally, there was also significant downregulation in p53 expression in group IV. A protective effect on oxidative DNA damage was reported for GSPE by Morin et al. (2008) when studied in rat leukocytes. Similarly, Praphasawat et al. (2011) reported the effectiveness of GSPE in reduction of the chromosome and DNA damage induced by mutagen and $\mathrm{H}_{2} \mathrm{O}_{2}$ radicals.

Bagchi et al. (2002) exhibited a series of mechanistic information of GSPE including free radical scavenging ability, inhibition of DNA topoisomerase II activity, anti-endonucleolytic activity, anti-necrotic, anti-carcinogenic and modulatory effects on some regulatory genes such as Bcl-2, c myc and p53. The protective effect of grape seed extract could be by the chelation of redox active metals, by the trapping of some reactive oxygen species and also by induction of expression of $\gamma$-glutamyl cysteine synthetase, the rate-limiting enzyme for GSH synthesis (Myhrstad et al., 2002). Grape seed extract by its GSH promoting activity, promotes vitamins $\mathrm{E}$ and $\mathrm{C}$ status, as these endogenous antioxidants are tightly linked (Balu et al., 2006).

\section{Conclusion}

Based on evidence presented in this study, it can be concluded that oral exposure to $\mathrm{K}$ dichromate resulted in increased oxidative stress, altered antioxidant status and DNA damage of small intestine in adult male albino rat. These findings predispose $\mathrm{K}$ dichromate to be carcinogenic to small intestine after oral intake especially the duodenum. Administration of GSPE along with $\mathrm{K}$ dichromate resulted in normalization of its toxic effects, thus highlighting the anticarcinogenic action of GSPE, by attenuating oxidative DNA damage.

\section{Recommendations}

Natural antioxidants including GSPE can serve as a type of preventive medicine. Using these agents as adjuvant to conventional therapeutic drugs augments their therapeutic effect at relatively lower doses, thereby limiting their toxic side effects to some extent. So, further studies are definitely needed to clarify issues related to human exposure to $\mathrm{K}$ dichromate and the protective effect of GSPE.

\section{References}

Ambreen K, Khan FH, Bhadauria S et al., (2012): Genotoxicity and oxidative stress in chromium-exposed tannery workers in north India. Toxicology and Industrial Health; 10: $1-10$.

Arakawa H, Weng MW, Chen WC et al., (2012): Chromium (VI) induces both bulky DNA adducts and oxidative DNA damage at adenines and guanines in the p53 gene of human lung cells. Carcinogenesis; 33(10): 1993-2000.

Arakawa H, Wu F, Costa M et al., (2006): Sequence specificity of Cr (III)-DNA adduct formation in the p53 gene: NGG sequences are preferential adduct-forming sites. Carcinogenesis; 27(3): 639-645.

Ariga T (2004): the antioxidative function, preventive action on disease and utilization of proanthocyanidins. Biofactors; 21 (1-4): 197201.

Bagchi D, Hassoun EA, Bagchi M et al., (1995): Oxidative stress induced by chronic administration of sodium dichromate (Cr VI) to rats. Comp Biochem Physiol; 110C:281287.

Bagchi D, Ray SD, Bagchi M et al., (2002): Mechanistic pathways of antioxidant cytoprotection by a novel IH636 grape seed proanthocyanidin extract. Indian J Exp Biol; 10: 717-726.

Balu M, Sangeetha P, Murali G et al., (2006): Modulatory role of grape seed extract on agerelated oxidative DNA damage in central 
nervous system of rats. Brain Research Bulletin; 68(6): 469-473

Banu SK, Stanley JA, Lee J et al., (2011): Hexavalent chromium-induced apoptosis of granulosa cells involves selective sub-cellular translocation of Bcl-2 members, ERK1/2 and p53. Toxicology and Applied Pharmacology; 251: 253-266.

Benhard D, Rossmann A, and Wick G (2005): Metals in cigarette smoke. IUBMB Life; 57:805-809

Bozzola JJ and Russel LD. (eds) (1999): Electron Microscopy Principles and Techniques for Biologists, Ch:7, The Scanning Electron Microscope. $2^{\text {nd }}$ edition, Jones and Bartlett Publisher, Boston. Pp, 202.

Couture O, Lombardi E, Davis K, et al., (2013): Gene Expression Profiles Resulting from Stable Loss of p53 Mirrors Its Role in Tissue Differentiation. ; 8(11): e82494.

Das DK (1999): Amelioration of cardiomyocyte apoptosis by IH636 grape seed proanthocanidin extract through the inhibition of JNK1 and Cjun. SFRR Euro. Wint. Meet. On Bio-flavinoids \& Polyphenols in health \& Disease. Dinard, France. OP 26.

Esrig D, Spruck CH 3rd, Nichols PW et al., (1993): p53 nuclear protein accumulation correlates with mutations in the p53 gene, tumor grade, and stage in bladder cancer. American Journal of Pathology. 143: 1389.

Gao F, Tomitori H, Igarashi K et al., (2002): Correlation between methotrexate induced intestinal damage and decrease inpolyamine content. Life Sci; 72: 669-676

Goulart M, Batoreu MC, Rodrigues AS et al., (2005): Lipoperoxidation products and thiol antioxidants in chromium exposed workers. Mutagenesis; 20:311-315.

He X, Lin GX, Chen MG et al., (2007): Protection against chromium (VI)-Induced oxidative stress and apoptosis by Nrf2. Recruiting Nrf2 into the nucleus and disrupting the nuclear Nrf2/Keap1 Association. Toxicological Sciences; 98(1):298-309

Hill R, Leidal AM, Madureira PA et al., (2008): Chromium-mediated apoptosis: Involvement of DNA-dependent protein kinase (DNA-PK) and differential induction of p53 target genes. DNA repair; 7: 1484-1499.

IARC (International Agency for Research on Cancer) (1990): Chromium. IARC Monogr Eval Carcinog Risks Hum. 49:49-256.

Izzotti A, Bagnasco M, Camoirano A et al., (1998): DNA-fragmentation, DNA-protein crosslinks, postlabeled nucleotidic modifications, and 8hydroxy-2'-deoxyguanosine in the lung but not in the liver of rats receiving intratracheal instillations of chromium (VI). Chemoprevention by oral $\mathrm{N}$-acetylcysteine. Mutat Res; 400: 233-244.

Jackson P and Blythe D (2008): Immunohistochemical techniques in Theory and Practice of Histological Technique, Bancroft JD and
Gample M. ElSevier, Sixth edition, China, $\mathrm{P}: 423$.

Khan FH, Ambreen K, Fatima G, et al., (2012): Assessment of health risks with reference to oxidative stress and DNA damage in chromium exposed population. Science of the Total Environment; 430: 68-74.

Kirman CR, Hays SM, Aylward LL et al., (2012): Physiologically based pharmacokinetic model for rats and mice orally exposed to chromium. Chem Biol Interact; 200(1):45-64.

Krebs RE (2006): The History and Use of our Earth's Chemical Elements:A Reference Guides econded.Greenwood Publishing Group, Santa Barbara,CA,p.96.

Krim M, Messaadia A, Maidi I et al., (2013): Protective effect of ginger against toxicity induced by chromate in rats. Ann Biol Clin (Paris); 71(2):165-73.

Kumar S and Roy S (2009): Effect of chromium on certain aspects of cellular toxicity. Iranian Journal of Toxicology; 2: 260-267.

Li ZH, Li P and Randak T (2011): Evaluating the toxicity of environmental concentrations of waterborne chromium (VI) to a model teleost, oncorhynchus mykiss: a comparative study of in vivo and in vitro. Comparative Biochemistry and Physiology Part C; 153: 402-407.

Lim SR and Schoenung JM (2010): Human health and ecological toxicity potentials due to heavy metal content in waste electronic devices with flat panel displays. Journal of Hazardous Materials; 177: 251-259.

Lou J, Wang Y, Yao C et al., (2013): Role of DNA methylation in cell cycle arrest induced by $\mathrm{Cr}$ (VI) in two cell lines. PLoS One 8: e71031.

Louwen F and Yuan J (2013): Battle of the eternal rivals: restoring functional $\mathrm{p} 53$ and inhibiting Polo-like kinase 1 as cancer therapy. Oncotarget; 4(7):958-71.

Lowry OH, Rosebrough NJ, Farr AI et al., (1951): Protein measurement with the Folin-Phenol reagent. J Biol Chem. 193, 265-275.

Mantena SK, Baliga MS and Katiyar SK (2006): Grape seed proanthocyandins induce apoptosis and inhibit metastasis of highly metastatic breast carcinoma cells. Carcinogenesis; 27:16821691.

Marilyn G (2008): The hematoxylin and eosin in Theory and Practice of Histological Technique, Bancroft JD and Gample M. sixth edition. Elsevier China. P: 121

Medeiros MG, Rodrigues AS, Batoréu MC et al., (2003): Elevated levels of DNA-protein crosslinks and micronuclei in peripheral lymphocytes of tannery workers exposed to trivalent chromium.Mutagenesis;18(1):19-24.

Menendez D, Inga A and Resnick MA (2009): The expanding universe of p53 targets. Nature Reviews Cancer; 9: 724-737.

Morin B, Narbonne JF, Ribera D et al., (2008): Effect of dietary fat-soluble vitamins $\mathrm{A}$ and $\mathrm{E}$ and 
Proanthocyanidin-rich extract from grape seeds on oxidative DNA damage. Food and Chemical Toxicology; 46: 787-796.

Motchnik AP, Frei B and Ames NB (1994): Measurement of antioxidants in human blood plasma: protein thiols. In: Packer, Ed. Oxygen radicals in biological systems; methods in enzymology. California: Academic Press 234, part D, pp. 273-4.

Muttigi MS, Kedage V, Surarna R et al., (2009): Serum GST activity and total thiols status in patients with liver disease secondary to various disorders. The Open Hepatology Journal; 1: 58.

Myhrstad MC, Carlsen H, Nordstrom O et al., (2002): Flavonoids increase the intracellular glutathione level by transactivation of the gamma-glutamylcysteine synthetase catalytical subunit promoter. Free Radic Biol Med; 32: 386-393

Naik SR and Panda VS (2007): Antioxidant and hepatoprotective effects of Ginkgo biloba phytosomes in carbon tetrachloride-induced liver injury in rodents. Liver Int; 27: 393-399

Nandakumar V, Singh T and Katiyar SK (2008): Multi-targeted prevention and therapy of cancer by proanthocyanidins.Cancer Lett; 269(2):378-87.

National Toxicology Program 'NTP' (2007): NTP Toxicity Report on the Toxicity Studies of Sodium Dichromate Dihydrate (CAS No. 7789-12-0) Administered in Drinking Water to Male and Female F344/N Rats and B6C3F1 Mice and Male BALB/c and am3-C57BL/6 Mice. Toxicity Report Series No. 72. NIH Publication No. 07-5964.

National Toxicology Program 'NTP' (2008): Technical report on the toxicology and carcinogenesis studies of sodium dichromate dihydrate (CAS No. 7789-12-0) in F344/N rats and $\mathrm{B} 6 \mathrm{C} 3 \mathrm{~F} 1$ mice (drinking water studies), NTP TR 546. NIH Publication No. pp. 08-5887.

Nickens KP, Patierno SR and Ceryak S (2010): Chromium genotoxicity: a double-edged sword. Chem Biol Interact; 188: 276-88.

NJDEP (2006): Report of the New Jersey Department of Environmental Protection, Report of the Chromium Work group. Accessed at: /http://www.state.nj.us/dep/dsr/chromium/cha pter \%203. pdfS (9.10.09).

O'Brien TJ, Ceryak S and Patierno SR (2003): Complexities of chromium carcinogenesis: role of cellular response, repair and recovery mechanisms. Mutat Res; 533:3-36.

Ohkawa H, Ohishi N and Yagi K (1979): Assay for lipid peroxides in animal tissues by thiobarbituric acid reaction. Anal Biochem; 95: 351-358.

Pechova A and Pavlata L (2007): Chromium as an essential nutrient: a review. Veterinarni Medicina; 52(1):1-18.
Pietsch EC, Sykes SM, McMahon SB, et al., (2008): The p53 family and programmed cell death. Oncogene; 27: 6507-6521.

Praphasawat R, Klungsupya P, Muangman T et al., (2011): Antimutagenicity and antioxidative DNA damage properties of oligomeric proanthocyanidins from thai grape seeds in TK6 cells. Ascian Pacific Journal of Cancer Prevention; 12: 1317-21.

Ray G, Batra S, Shukla NK et al., (2000): Lipid peroxidation, free radical production and antioxidant status in breast cancer. Breast Cancer Res Treat; 59: 163-170.

Seidler A, Jähnichen S, Hegewald J et al., (2013): Systemic review and quantification of respiratory cancer risk for occupational exposure to hexavalent chromium. Int. Arch. Occup. Enviorn. Health; 86(8): 943-55.

Sellappa S, Prathyumnan S, Joseph S et al., (2011): Micronucleus test in exfoliated buccal cells from chromium exposed tannery workers. International Journal of Bioscience, Biochemistry and Bioinformatics; 1: 58-62.

Sen S, Chakraborty R, Sridhar C et al., (2010): Free radicals, antioxidants, disease and phytomedicines: status and future prospect. International Journal of Pharmaceutical Sciences Review and Research; 3: 91-100.

Serra S and Jani PA (2006): An approach to duodenal biopsies. J Clin Pathol; 59(11): 1133-50.

Slooff W (1989): Integrated criteria document chromium. National Institute of Public Health and EnvironmentalProtection, Bilthoven, Netherlands, Report no.758701002.

Srihari T, Selvam JP, Aranganathan S et al., (2008): Escalation of circulatory antioxidants by organo (Origanum Vulgare L.) during 1,2dimethylhydazine induced experimental colon carcinogenesis: Journal of cell and tissue research; 8(2): 1405- 1410.

Stoecker JB (2004): Chromium. In Elements and their compounds in the environment 2 nd edition, pp 709-729. Eds Merian E, Anke M, Ihnat M, Stoeppler M. Copyright, Weinheim, Germany.

Sutton R. (2010): Chromium-6 in US Tap Water. Environmental Working Group; 10. pp. 1-22

Tang Q, Zou P and Jin H (2012): Grape seed proanthocyanidins ameliorate contact hypersensitivity induced by dinitrofluorobenzene (DNFB) and inhibit $\mathrm{T}$ cell proliferation in vitro. Toxicology Letters; 210(1): 1- 8 .

Thompson CM, Fedorov Y, Brown DD et al., (2012): Assessment of $\mathrm{Cr}(\mathrm{VI})$ - induced cytotoxicity and genotoxicity using high content analysis. PLoS One; 7(8): 42720.

Thompson CM, Haws LC, Harris MA et al., (2011): Application of the U.S. EPA mode of action Framework for purposes of guiding future research: a case study involving the oral carcinogenicity of hexavalent chromium. Toxicol Sci; 119: 20-40. 
Tomasevic G, Raghupathi R, Scherbel U et al., (2010): Deletion of the p53 tumor suppressor gene improves neuromotor function but does not attenuate regional neuronal cell loss following experimental brain trauma in mice. Journal of Neuroscience Research; 88: 3414-3423.

Turpeenoja L, Villa R, Magri G et al., (1988): Changes of mitochondrial membrane proteins in rat cerebellum during aging. Neurochem Res; 13: $859-865$.

USEPA (2005): Guidelines for Carcinogen Risk Assessment, EPA/630/P-03/001F. Washington, D.C: Risk Assessment Forum: U.S. Environmental Protection Agency.

Valavanidis A, Vlahogianni T, Dassenakis $M$ and Scoullos M (2006): Molecular biomarkers of oxidative stress in aquatic organisms in relation to toxic environmental pollutants. Ecotoxicol Environ Saf 64: 178-189.

Valko M, Morris H and Cronin MTD (2005): Metals, toxicity and oxidative stress. Current Medicinal Chemistry; 12: 1161-1208.

Valko M, Rhodes CJ, Moncol J et al., (2006): Free radicals, metals and antioxidants in oxidative stress-induced cancer. Chem Biol Interact; 160:1-40.

Verburg M, Renes IB, Meijer HP et al., (2000): Selective sparing of goblet cells and paneth cells in the intestine of methotrexate-treated rats. Am J Physiol Gastrointest Liver Physiol; 279: 1037-1047.

Wise Sr JP, Wise SS, Holmes AL et al., (2010): The cytotoxicity and genotoxicity of hexavalent chromium in Steller sea lion lung fibroblasts compared to human lung fibroblasts. Comparative Biochemistry and Physiology Part C: Toxicology \& Pharmacology; 152(1): 91-98

Xiao F, Chen D, Luo L et al., (2013): Time-order effects of vitamin $\mathrm{C}$ on hexavalent chromium-induced mitochondrial damage and DNA-protein crosslinks in cultured rat peripheral blood lymphocytes. Mol Med Rep; 8(1):53-60.

Yan HX, Wu HP, Zhang HL et al., (2013): DNA damage- induced sustained p53 activation contributes to inflammation- associated hepatocarcinogenesis in rats. Oncogene 32(38)): 4565-71.

Zitnan R, Kuhla S, Nurnberg K et al., (2003): Influence of the diet on the morphology of ru-minal and intestinal mucosa and on intestinal carbohydrate levels in cattle. Veterinatni Medicina; 48: 177-182.

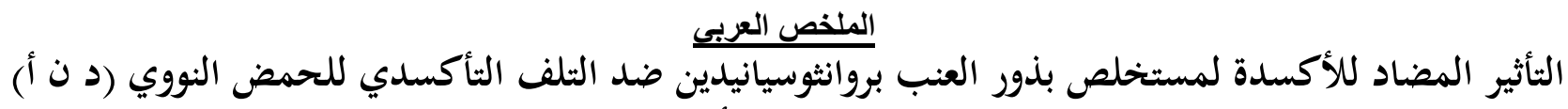

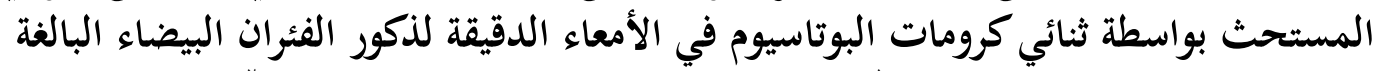

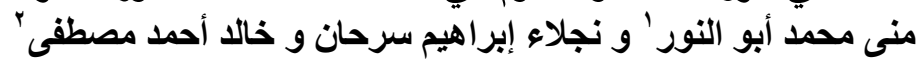

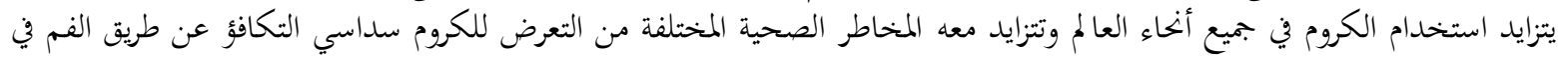

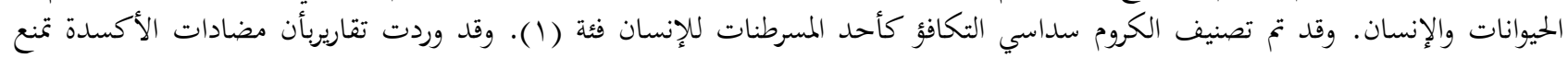

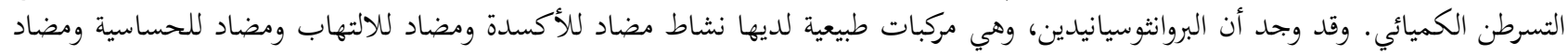

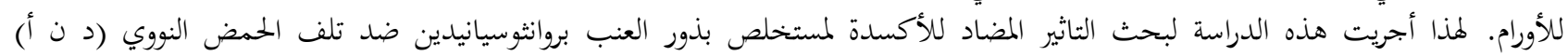

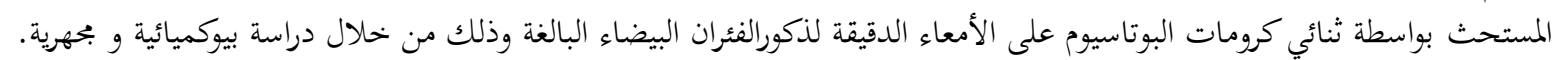

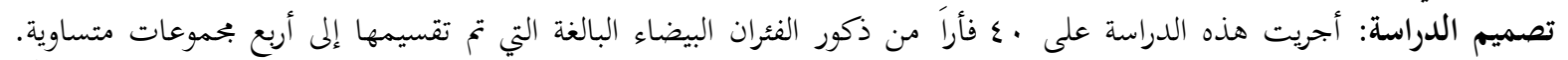

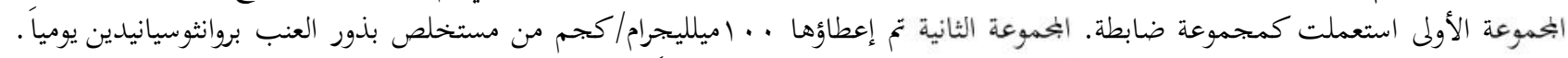

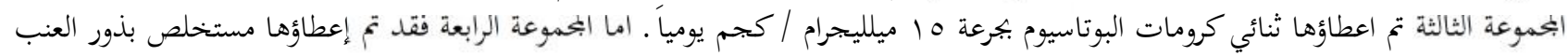

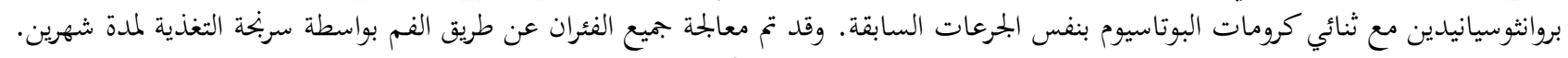

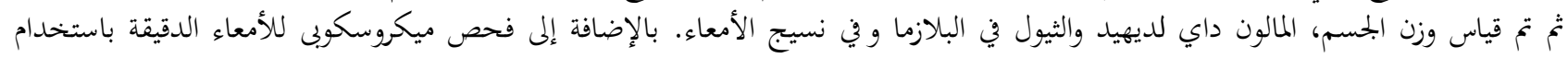

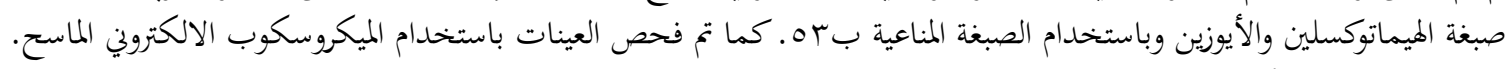

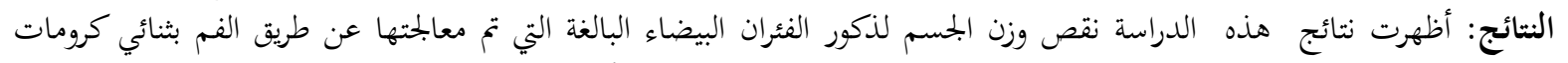

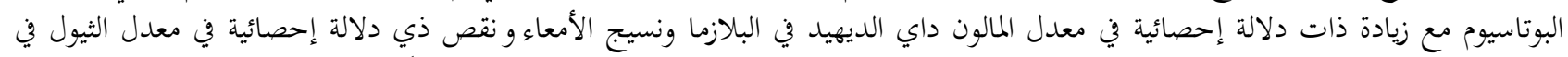

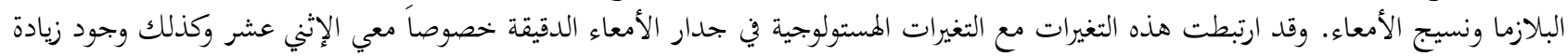

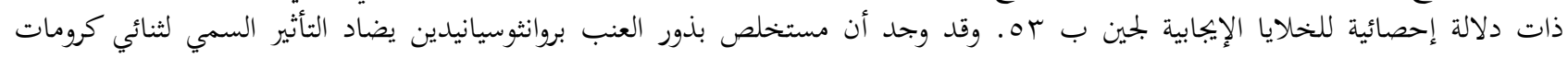

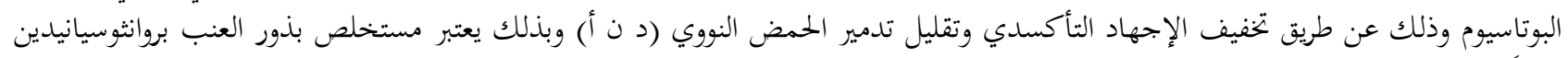

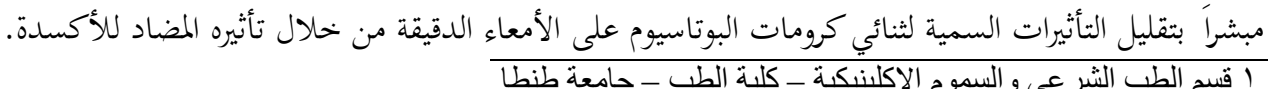

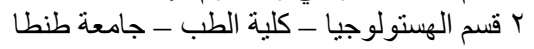

